\title{
PENINGKATAN HASIL BELAJAR SOSIOLOGI POKOK BAHASAN PERUBAHAN SOSIAL (CONTRAVENTION) MELALUI METODE PEMBELAJARAN TEAM ACCELERATE DINTRUCTION PADA SISWA KELAS XII SMA NEGERI 1 BONTOMARANNU KABUPATEN GOWA.
}

\author{
Arfenti Amir 1) \\ Universitas Megarezky \\ arfenti79@gmail.com \\ Irwan Nur 2) \\ Universitas Megarezky \\ irwanxaminah@gmail.com
}

\begin{abstract}
Masalah utama dalam penelitian ini yaitu bagaimana meningkatkan hasil belajar sosiologi pokok bahasan perubahan sosial (Contravention) melalui metode pembelajaran Team Accelerated Intruction pada siswa kelas XII SMA Negeri 1 Bontomarannu Kabupaten Gowa. Penelitian ini bertujuan untuk peningkatan hasil belajar sosiologi pokok bahasan perubahan sosial (Contravention) melalui Metode pembelajaran Team Accelerated Intruction pada siswa kelas XII SMA Negeri 1 Bontomarannu Kabupaten Gowa Jenis penelitian ini adalah penelitian tindakan kelas (PTK) yang terdiri dari dua siklus dengan 4 tahapan, yaitu: perencanaan, tindakan, observasi dan refleksi yang dilakukan secara berulang. Guru sebagai salah satu komponen penting dalam kegiatan belajar mengajar, memiliki peran ganda yakni sebagai pengajar dan sebagai pendidik. Selain sebagai pengajar dan pendidik, guru juga memiliki peran yang sangat besar dalam pengelolaan kelas. Dengan pemaksimalan fungsi dan peran guru akan berimplikasi pada perbaikan dan peningkatan proses pembelajaran yang salah satu indikatornya berupa peningkatan hasil belajar siswa.Salah satu kemampuan yang diharapkan dikuasai oleh pendidik dalam hal ini adalah bagaimana mengajarkan sosiologi dengan baik dan benar agar tujuan pengajaran dapat dicapai semaksimal mungkin.

Pengajaran sosiologi di sekolah menengah berfungsi untuk meningkatkan kemampuan siswa mengaktualisasikan potensi-potensi diri mereka dalam memahami dan mengungkapkan berbagai perubahan sosial yang ada dewasa ini.Materi peubahan Sosial merupakan salah satu materi pelajaran sosiologi yang di ajarkan di kelas XII SMA/MAN sederajat.
\end{abstract}

Kata Kunci: Peningkatan, Perubahan Sosial, Pembelajaran Team Accelerate

\section{PENDAHULUAN}

Pada dasarnya pendidikan bisa dihargai dan dengan adanya amatlah penting bagi kehidupan manusia pendidikan pula kita bisa meraih cita-cita karena dengan adanya pendidikan kita 
olehnya itu pendidikan amatlah penting bagi kita.

Pendidikan pada hakekatnya untuk meningkatkan kualitas manusia seutuhnya, oleh karena itu perlu diadakan upaya peningkatan mutu pendidikan dimasa kini dan yang akan datang. Namun dalam pelaksanaannya pendidikan selalu menghadapi tantangan, misalnya masalah kualitas, relevansi, pemerataan dan sebagainya. Masalah mutu pendidikan adalah suatu tantangan dalam pendidikan,apalagi dalam era globalisasi sekarang ini pendidikan mempunyai peranan penting dalam mencapai cita-cita.

$$
\text { Munib, }
$$

mengemukakan bahwa pendidikan merupakan suatu proses untuk mengembangkan semua aspek kepribadian manusia yang mencakup pengetahuan, nilai sikap, dan keterampilannya. Pendidikan bertujuan untuk mencapai kepribadian suatu individu yang lebih baik. Pendidikan mengembang tugas untuk menghasilkan generasi yang lebih baik, manusia yang lebih berkebudayaan, dan manusia yang memiliki kepribadian yang lebih baik. Dengan penegasan di atas berarti peningkatan kualitas sumber daya manusia haruslah dilakukan dalam konteks peningkatan pengetahuan dan keterampilan melalui model pengajaran yang efektif dan efesien serta mengikuti perkembangan teknologi.

Guru merupakan salah satu faktor penting yang akan menentukan tinggi rendahnya mutu pendidikan. rendahnya mutu pendidikan disebabkan oleh 4 faktor yaitu: jumlah guru yang belum memadai serta penyebarannya belum merata, kondisi sarana dan prasarana yang belum memadai, anggaran pendidikan yang jumlahnya sangat terbatas, serta proses pembelajaran yang belum efektif

Guru sebagai salah satu komponen penting dalam kegiatan belajar mengajar, memiliki peran ganda yakni sebagai pengajar dan sebagai pendidikan. Selain sebagai pengajar dan pendidik, guru juga memiliki peran yang sangat besar dalam pengelolaan kelas. Dengan pemaksimalan fungsi dan peran guru akan berimplikasi pada perbaikan dan peningkatan proses pembelajaran yang salah satu indikatornya berupa peningkatan hasil belajar siswa.Salah satu kemampuan yang diharapkan dikuasai oleh pendidik dalam hal ini adalah bagaimana mengajarkan sosiologi dengan baik dan benar agar tujuan pengajaran dapat dicapai semaksimal mungkin. Dalam hal ini penguasaan materi dan cara memilih pendekatan atau teknik 
pembelajaran yang sesuai dengan penentuan tercapainya tujuan pengajaran dan tuntutan kurikulum yang berlaku.

Sosiologi mempunyai dua pengertian, yaitu sebagai ilmu dan sebagai metode. Sebagai ilmusosiologi merupakan kumpulan pengetahuan tentang masyarakat dan kebudayaan yang disusun secara sistematik berdasarkan analisis berpikir logis. Sebagai metode, sosiologi adalah cara berfikir untuk mengungkapkan realitas sosial dan budaya yang ada dalam masyarakat dengan prosedur dan teori yang dapat dipertanggungjawabkan secara ilmiah.

Pengajaran sosiologi di sekolah menengah berfungsi untuk meningkatkan kemampuan siswa mengaktualisasikan potensi-potensi diri mereka dalam memahami dan mengungkapkan berbagai perubahan sosial yang ada dewasa ini.Materi peubahan Sosial merupakan salah satu materi pelajaran sosiologi yang di ajarkan di kelas XII SMA/MAN sederajat.

Setiap kehidupan masyarakat manusia senantiasa mengalami suatu perubahan. Perubahan-perubahan pada kehidupan masyarakat tersebut merupakan fenomena sosial yang wajar, oleh karena itu setiap manusia mempunyai kepentingan yang tak terbatas.
Pada dasarnya perubahanperubahan sosial terjadi,oleh karena anggota masyarakat pada waktu tertentu merasa tidak puas lagi terhadap keadaan kehidupannya yang lama. Contohnya kecurigaan yang masih ada terhadap seseorang yang sering dijumpai atau ditemui atau apabila suatu rencana yang telah ditetapkan oleh pemerintah diragukan kegunaannya oleh masyarakat maka timbullah suatu pertentangan. maka terjadilah tindak perubahan dalam bentuk contravention.

\section{Kontravensi ( Contravention )} merupakan suatu bentuk proses sosial yang berada antara persaingan dan pertentangan atau pertikaian.

Kontravensi terutama ditandai oleh gejala-gejala adanya ketidakpastian mengenai diri seseorang atau suatu rencana dan perasaan tidak suka yang disembunyikan, kebencian, atau keraguraguan terhadap kepribadian seseorang. Atau perasaan tersebut dapat pula berkembang terhadap kemungkinan, kegunaan, keharusan atau penilaian terhadap suatu usul, buah pikiran, kepercayaan, doktrin, atau rencana yang dikemukakan orang-perorangan atau kelompok manusia lain.

Dalam pembelajaran sosiologi bagi siswa terkadang dianggap tidak 
efisien dan menjenuhkan, sehingga banyak siswa yang kurang merespon atau minat belajarnya kurang karena mereka tidak mengetahui cara belajar yang efektif. Seperti diketahui belajar belajar itu sangat kompleksTentunya salah faktornya adalah kelalaian dan menjadi permasalahan dalam pembelajaran sosiologi disekolah dan metode pembelajaran bagi guru dan siswa dalam penyajiannya tidak relevan dengan konteks sosial.

Untuk meningkatkan jumlah siswa yang mengalami ketuntasan dalam belajar sosiologi, diperlukan suatu model pembelajaran dan metode mengajar yang berbeda dari sebelumnya, yang membuat siswa dapat menggunakan dan mengingat lebih lama konsep dan penerapan sosiologi, seorang guru harus dapat berkomunikasi baik dengan siswanya, guru dapat membuka wawasan berpikir yang beragam dari seluruh siswa, sehingga siswa dapat mempelajari seluruh konsep dan cara mengaitkannya dalam kehidupan nyata. Jika hal ini tercapai, tentunya siswa tidak lagi jenuh belajar sosiologi, bahkan siswa yang tadinya minat belajarnya kurang menjadi bersemangat dan mulai menyukai pelajaran sosiologi sedikit demi sedikit. Salah satu model pembelajaran yang dapat membuat siswa menjadi lebih aktif, dapat menyelesaikan soal-soal berbentuk masalah, menumbuhkan kembali motivasi dan minat siswa dalam belajar, adalah strategi pembelajaran peningkatan kemampuan berpikir. Strategi pembelajaran peningkatan kemampuan berpikir suatu strategi pembelajaran yang didasarkan pada pengembangan kemampuan berpikir siswa melalui telaahan fakta-takta sosial atau pengalaman anak sebagai bahan untuk memecahkan masalah yang diajukan. Misalnya hukum, adat kebiasaan, norma, agama, bahasa dan tatanan kehidupan lainnya. Dari contoh permasalahan nyata jika diselesaikan secara nyata, memungkinkan siswa memahami konsep bukan sekedar menghafal konsep.

\section{TINJAUAN PUSTAKA}

\section{Hakikat Belajar}

a. Pengertian Belajar

Belajar merupakan suatu proses perubahan tingkah laku seseorang sebagai hasil dari interaksi dengan lingkungannya dalam memenuhi kebutuhan hidupnya. Perubahan tersebut nyata dalam aspek tingkah laku. Sebagaimana yang dikemukakan oleh Gage dan Berliner, yang mendefinisikan belajar sebagai suatu proses yang membuat seseorang mengalami 
perubahan tingkah laku sebagai hasil dari pengalaman yang diperolehnya. Hal ini senada dengan yang dikemukakan oleh Slameto (1995: 2) bahwa: "Belajar adalah suatu proses usaha yang dilakukan seseorang untuk memperoleh suatu perubahan tingkah laku yang baru secara keseluruhan, sebagai hasil pengalamannya sendiri dalam interaksi dengan lingkungannya". Sedangkan John Dewey, menekankan bahwa oleh karena belajar menyangkut apa yang harus dikerjakan murid-murid untuk dirinya sendiri, maka inisiatif harus datang dari murid-murid sendiri. Guru adalah pembimbing dan pengarah, yang mengemudikan perahu, tetapi tenaga untuk menggerakkan perahu tersebut haruslah berasal dari murid yang belajar.

Dari beberapa batasan yang dikemukakan oleh beberapa pakar di atas, dapat disimpulkan bahwa belajar merupakan suatu proses yang melibatkan manusia secara orang perorang sebagai satu kesatuan organisasi sehingga terjadi perubahan pengetahuan, keterampilan, dan sikapnya. Orang yang belajar adalah orang yang mengalami sendiri proses belajar, sehingga dalam belajar orang tidak mungkin melimpahkan tugas-tugas belajarnya kepada orang lain. Proses belajar yang melibatkan secara aktif orang yang belajar seperti yang telah dikemukakan merupakan salah bentuk upaya dalam meningkatkan kreatifitas siswa dalam menyelesaikan masalahmasalah sosiologi.
b. Hakikat pembelajaran sosiologi

Kata sosiologi berasal dari kata lain socius yang artinya teman,dan kata bahasa yunani logos yang berarti cerita,diungkapkan pertama kali dalam buku yang berjudul "Course De Philosophie Positive"karangan August Comte (1798-1857).sosiologi muncul sejak ratusan,bahkan ribuan tahun lalu.Namun,sebagai ilmu yang mempelajari masyarakat,sosiologi baru lahir kemudian di Eropa yang sejak awal abad ke-19 dapat dikatakan sebagai pusat tumbuhnya peradaban dunia.

Pitirin Sorokin membatasi sosiologi sebagai ilmu yang mempelajari hubungan dan pengaruh timbal balik antar aneka macamgejala-gejala sosial seperti:antara gejala ekonomi dan agama,keluarga dan moral,hukum dan ekonomi,gerakan masyarakat dan politik,dan sebagainya,hubungan pengaruh dan timbal balik antar gejalagejala sosial dan nonsosial seperti gejala geografis, biologis dan sebagainya, dan ciri- 
ciri umum dari semua jenis gejala-gejala sosial.

Soemardjan

dan

Soemardi(Abdulsyani, 2002), mengatakan

bahwa sosiologi atau ilmu masyarakat adalah ilmu yang mempelajari struktur sosial dan proses sosial, termasuk perubahan-perubahan sosial. Y.B.A.F Mayor Polak (Abdulsyani, 2002), bahwa sosiologi adalah ilmu pengetahuan yang mempelajari masyarakat sebagai keseluruhan, yakni antar hubungan diantara manusia dengan manusia, manusia dengan kelompok, kelompok

c. Hasil Belajar

Sasaran dari kegiatan belajar adalah hasil belajar. Apabila proses belajar berjalan dengan baik, maka hasil belajar juga akan baik pula. Artinya hasil belajar harus bisa dimanfaatkan sebaik-baiknya oleh pengajar dalam menyelesaikan suatu masalah dan sebagai pertimbangan dalam langkah selanjutnya. Hasil belajar adalah prestasi yang dicapai oleh siswa setelah mengikuti proses belajar mengajar yang berkenaan dengan materi suatu mata pelajaran. Hasil belajar ini dapat diukur dengan menggunakan tes hasil belajar.

Hasil belajar adalah hasil yang dicapai oleh siswa yang telah mengikuti proses belajar mengajar merupakan variabel belajar yang hanya dapat diukur dengan tes prestasi belajar. dalam kamus ilmiah bahwa kata " prestasi " berarti hasil yang dicapai karena kemampuan yang dimiliki.

Menurut Gulo belajar diartikan sebagai usaha untuk mengubah tingkah laku. Belajar adalah suatu proses yang berlangsung didalam diri seseorang yang mengubah tingkah lakunya, baik tingkah laku dalam berpikir, bersikap dan berbuat.

Menurut Tirtaraharja prestasi belajar siswa adalah hasil yang diperoleh siswa dari pekerjaan yang dilakukannya yang ditandai dengan perubahan individu dalam kebiasaan sikap yang didapat dinilai dari proses belajar yang dicapai siswa.

Secara garis besar menurut Slameto ada dua faktor yang dapat mempengaruhi prestasi belajar yaitu; (i) faktor internal, adalah faktor yang menyangkut seluruh aspek pribadi siswa, baik fisik maupun mental atau psikisnya yang ikut menentukan berhasil tidaknya seseorang dalam belajar yang meliputi jasmani, kondisi psikologi dan (ii) faktor eksternal, meliputi faktor keluarga, faktor sekolah dan faktor masyarakat.

Dalam proses belajar mengajar, hasil belajar yang diharapkan dapat dicapai siswa penting diketahui oleh guru, agar guru dapat merencanakan/mendesain pengajaran 
secara tepat dan penuh arti. Setiap proses belajar mengajar keberhasilannya diukur dari seberapa jauh hasil belajar yang dicapai siswa, di samping diukur dari segi prosesnya. Artinya seberapa jauh hasil belajar di miliki siswa.

Benyamin Bloom (Sujana, berpendapat bahwa tujuan pendidikan yang hendak dicapai digolongkan menjadi tiga bidang, yakni kognitif, afektif, dan psikomotorik.

1. Faktor yang Mempengaruhi Hasil Belajar

Menurut Slameto faktor-faktor yang mempengaruhi hasil belajar adalah:

a. Faktor interen yang terdiri dari:

- faktor jasmaniah seperti kesehatan, cacat tubuh.

- faktor psikologi antara lain: perhatian, minat, bakat dan motivasi

- faktor kelelahan. Dapat dibedakan menjadi dua macan yaitu: kelelahan jasmani terlihat dengan lemah lunglainya tubuh timbul kecenderungan untuk membaringkan tubuh dan kelelahan rohani dapat dilihat dengan adanya kelesuan dan kebosanan sehingga minat dan dorongan untuk sesuatu hilang. b. Faktor eksteren yang terdiri dari:

- Faktor keluarga meliputi: cara orang tua mendidik, relasi antar anggota keluarga, suasana rumah, keadaan ekonomis keluarga, pengertian orang tua dan latar belakang kebudayaan.

- Faktor sekolah meliputi: guru sebagai pengajar, metode mengajar, alat pengajaran, disiplin sekolah, relasi guru dengan siswa, waktu sekolah dan standar pelajaran di atas ukuran.

\section{Pokok Bahasan Materi dan Perubahan Sosial}

\section{a. Pengertian Perubahan Sosial}

Perubahan sosial adalah segala perubahan pada lembaga-lembaga kemasyarakatan di dalam suatu masyarakat, yang memengaruhi sistem sosialnya, termasuk didalamnya nilainilai,sikap-sikap dan pola-pola perilaku di antara kelompok-kelompok dalam masyarakat.

\section{Menurut Beberapa ahli:}

Roucek dan Warren perubahan sosial adalah perubahan dalam proses sosial atau dalam struktur masyarakat. 
selo Soemardjan dan Soelaiman Soemardi, berpendapat bahwa perubahan-perubahan sosial adalah segala perubahan-perubahan pada lembaga-lembaga kemasyarakatan di dalam suatu masyarakat, yang mempengaruhi sistem sosialnya, termasuk didalamnya nilai-nilai, sikap-sikap dan pola-pola perikelakuan di antara kelompok-kelompok dalam masyarakat.

William F. Ogburn berpendapat perubahan-perubahan sosial meliputi unsur-unsur kebudayaan baik yang material maupun yang immaterial,yang ditekankan adalah pengaruh besar unsurunsur kebudayaan material terhadap unsur-unsur immaterial.

Kingsley Davis) berpendapat perubahan sosial sebagai perubahanperubahan yang terjadi dalam struktur dan fungsi masyarakat.

Maclvermengatakan perubahan sosial sebagai perubahan-perubahan dalam hubungan sosial (social relationships) atau sebagai perubahan terhadap keseimbangan ( equilibrium) hubungan sosial.

Gillin dan Gillin berpendapat perubahan sosial sebagai suatu variasi dari cara-cara hidup yang telah diterima, baik karena perubahan-perubahan kondisi geografis,kebudayaan materiil,komposisi penduduk, ideologi maupun karena adanya difusi ataupun penemuanpenemuan baru dalam masyarakat.

Samuel Koenig mengatakan bahwa perubahan sosial menunjuk pada modifikasi-modifikasi yang terjadi dalam pola-pola kehidupan manusia yang terjadi karena sebab-sebab intern maupun sebab-sebab ekstern.

Bruce J. Cohen, mengemukakan bahwa perubahan sosial adalah perubahan struktur sosial dan perubahan pada organisasi sosial.

Soedjono

Dirdjosisworo merumuskan definisi perubahan sosial sebagai perubahan fundamental yang terjadi dalam struktur sosial,sistem sosial dan organisasi sosial.

Pitirim A. Sorokin) berpendapat bahwa segenap usaha untuk mengemukakan adanya suatu kecenderungan yang tertentu dan tetap dalam perubahan-perubahan sosial tidak akan berhasil baik.

b. Faktor-faktor

Penyebab

\section{Perubahan Sosial}

Pada dasarnya perubahanperubahan sosial terjadi, oleh karena anggota masyarakat pada waktu merasa tidak puas lagi terhadap keadaan kehidupannya yang lama. ada tiga faktor 
penyebab utama dalam perubahan sosial,yaitu:

1. Timbunan kebudayaan dan penemuan baru :

Timbunan

kebudayaan,merupakan faktor penyebab perubahan sosial yang penting. kebudayaan dalam kehidupan masyarakat senantiasa terjadi penimbunan, yaitu suatu kebudayaan semakin lama semakin beragam dan bertambah secara akumulatif. dan bertimbunnya kebudayaan ini oleh karena adanya penemuan baru dari anggota masyarakat pada umumnya.

Menurut Koentjaraningrat, faktorfaktor yang mendorong individu untuk mencari penemuan baru adalah sebagai berikut:

$>\quad$ Kesadaran dari orang perorangan akan kekurangan dalam kebudayaannya.

Kualitas dari ahli-ahli dalam suatu kebudayaan.

perangsang bagi aktivitasaktivitas penciptaan dalam masyarakat.

2. Perubahan Jumlah Penduduk

Perubahan jumlah penduduk juga merupakan penyebab terjadinya perubahan sosial, seperti pertambahan atau berkurangnya penduduk pada suatu daerah tertentu. Bertambahnya penduduk pada suatu daerah, dapat mengakibatkan perubahanpada struktur masyarakat, terutama mengenai lembaga-lembaga kemasyarakatannya.

3. Pertentangan (Conflit)

Pertentangan antara anggotaanggota masyarakat dapat terjadi karena perubahan masyarakat yang pesat, sebagaimana dijelaskan oleh Roucek dan Warren. Masyarakat yang heterogen biasanya ditandai kurang dekatnya hubungan antara orang satu dengan orang atau kelompok lainnya; individu cenderung mencari jalannya sendiri-sendiri.

\section{c. Bentuk-bentuk Perubahan Sosial}

Perubahan-perubahan sosial yang terjadi dalam masyarakat dapat dibedakan atas beberapa bentuk, yaitu perubahan evolusi dan perubahan revolusi, perubahan tak berencana dan perubahan berencana

1. Perubahan evolusi dan perubahan revolusi, adalah perubahan-perubahan sosial yang terjadi dalam proses yang lambat, dalam waktu yang cukup lama dan tanpa ada kehendak tertentu dari masyarakat yang bersangkutan. Menurut Soerjono, syarat-syarat terjadinya suatu revolusi adalah sebagai berikut: a. ada keinginan umum mengadakan suatu perubahan. di dalam masyarakat harus ada perasaan tidak puas terhadap 
keadaan, dan harus ada suatu keinginan untuk mencapai perbaikan dengan perubahan keadaan tersebut.

b. adanya seorang pemimpin atau sekelompok orang yang dianggap mampu memimpin masyarakattersebut.

c. pemimpin tersebut harus dapat menunjukkan suatu tujuan pada masyarakat. artinya adalah bahwa tujuan tersebut terutama sifatnya konkret dan dapat dilihat oleh masyarakat. disamping itu diperlukan juga suatu tujuan yang abstrak, misalnya perumusan sesuatu ideologi tersebut.

2. yang direncanakan dan perubahan yang tidak di rencanakan

perubahan yang direncanakan adalah perubahan-perubahan terhadap lembaga-lembaga kemasyarakatan yang didasrkan pada perencanaan yang matang oleh pihak-pihak yang menghendaki perubahan-perubahan tersebut menurut Selo Soemardjan dan Soelaiman Soemardi, perubahan yang direncanakan adalah perubahan yang diperkirakan atau yang telah direncanakan terlebih dahulu sebelumnya oleh pihakpihak yang hendak mengadakan perunahan didalam masyarakat. pihakpihak yang menghendaki suatu perubahan dinamakan agent of change, yaitu seseorang atau sekelompok orang yang mendapatkan kepercayaan dari masyarakat sebagai pemimpin satu atau lebih lembaga-lembaga kemasyarakatan.

Suatu perubahan yang direncanakan, selalu berada dibawah pengendalian atau pengawasan dari agent of change tersebut. pelaksanaan rencana perubahan tidak hanya terbatas pada lembaga-lembaga kemasyarakatan tertentu saja,melainkan bisa juga diarahkan pada perubahan-perubahan bagi lembaga-lembaga kemasyarakatan yang lain dan dalam tubuh masyarakat yanmg lain pula.

\section{d. Faktor-faktor yang Memengaruhi Jalannya Proses Perubahan}

a. kontak dengan kebudayaan lain

b. sistem pendidikan yang maju

c. sikap menghargai hasil karya seseorang dan keinginankeinginan untuk maju

d. toleransi terhadap perbuatanperbuatan menyimpang

e. sistem lapisan masyarakat terbuka

f. penduduk yang heterogen

g. ketidakpuasaan masyarakat terhadap bidang-bidang kehidupan tertentu

h. orientasi kemasa depan

i. Nilai meningkatkan taraf hidup 
e. Faktor-faktor yang menghambat terjadinya perubahan

a. kurangnya hubungan dengan masyarakat-masyarakat lain

b. perkembangan ilmu pengetahuan yang terlambat

c. sikap masyarakat yang tradisonalistis

d. adanya kepentingankepentingan yang telah tertanam dengan kuat atau vested interest

e. rasa takut akan terjadinya kegoyahan pada integrasi kebudayaan

f. prasangka terhadap hal-hal yang baru/asing

g. hambatan ideologis

h. kebiasaan

i. nilai pasrah

\section{f. Teori-teori dalam perubahan sosial}

Menurut Lauer ada 2 teori utama perubahan sosial:

a. Teori siklus

Teori siklus melihat perubahan merupakan sesuatu yang berulang-ulang, tidak dapat direncanakan atau diarahkan ketitik tertentu. Tidak ada proses perubahan masyarakat secara bertahap sehingga batas antara pola hidup primitif, tradisional dan modern tidak jelas.

\section{Metode Pembelajaran Team Accelerated Instruction}

1. Pengertian Pembelajaran Team Accelerated Instruction

Pembelajaran kooperatif Team Accelerated Instruction ini, dikembangkan oleh Slavin. Tipe ini mengkombinasikan keunngulan pembelajaran kooperatif dengan individual. Tipe ini dirancang untuk mengatasi kesulitan belajar siswa secara indivual. Oleh karena itu pembelajarannya lebih banyak digunakan untuk pemecahan masalah.

Ciri khas tipe Team Accelerated Instruction adalah setiap siswa secara individual belajar materi pembelajaran yang sudah dipersiapkan oleh guru. Hasil belajar individual dibawa kekelompokkelompok untuk didiskusikan untuk dibahas oleh anggota kelompok, dan semua anggota kelompok bertanggub jawab atas keseluruhan jawaban sebagai tanggub jawab bersama.

Metode Pembelajaran Team Accelerated Instruction, dalam metode ini, siswa dikelompokkan berdasarkan kemampuan yang beragam. masingmasing kelompok terdiri dari 4 siswa dan ditugaskan untuk menyelesaikan materi pembelajaran atau PR tertentu.

Dalam metode pembelajaran

Team Accelerated Instruction, setiap 
kelompok diberi serangkain tugas tertentu untuk dikerjakan bersama-sama. poin-poin dalam tugas dibagikan secara berurutan kepada sitiap anggota. semua anggota harus saling mengecek jawaban temanteman satu kelompoknya dan saling memberi bantuan jika memang dibutuhkan.

Dalam metode Team Accelerated Instruction siswa harus saling mengecek pekerjaannya satu sama lain mengerjakan tugas berdasarkan rangkaian soal tertentu, guru sambil lalu bisa memberi penjelasan seputar soal-soal yang kebanyakan dianggap rumit oleh siswa.

Dalam metode pembelajaran Team Accelerated Instruction, Akuntabilitas individu,kesempatan yang sama untuk sukses, dan dinamika motivasional menjadi unsur-unsusr utama yang harus ditekankan oleh guru.

\section{METODE PENELITIAN}

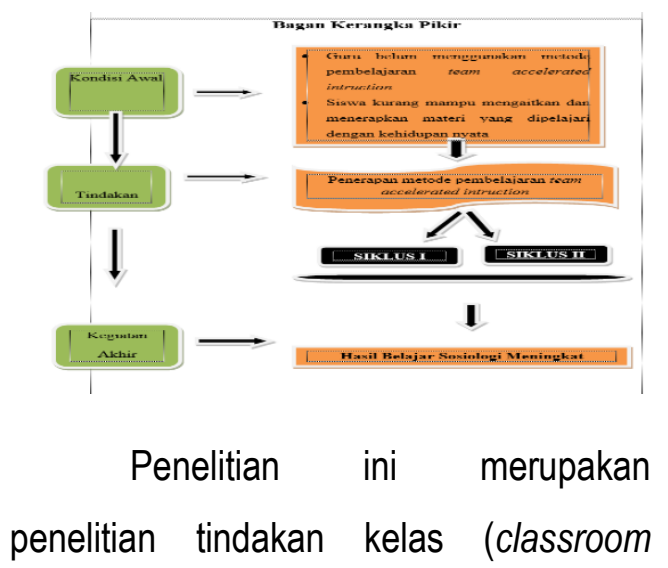

action research) yang berusaha untuk menemukan dan memecahkan masalah di dalam kegiatan belajar mengajar.Penelitian ini terdiri dari dua siklus dengan tahapan-tahapan pelaksanaan meliputi perencanaan, pelaksanaan tindakan, evaluasi dan refleksi secara langsung yang selanjutnya tahapan-tahapan tersebut dirangkai dalam satu siklus kegiatan.

\section{A. Lokasi Waktu dan Subyek Penelitian}

Penelitian ini dilaksanakan di SMA Negeri 1 Bontomarannu dan penelitian ini dilaksanakan selama dua bulan pada bulan Oktober-November semester ganjil tahun ajaran 2018/2019. Subjek dalam penelitian ini adalah siswa kelas XII SMA Negeri 1 Bontomarannu, dengan menggunakan sampel siswa kelas XII tahun ajaran 2018/2019 semester ganjil. Yang berjumlah 31orang siswa, perempuan 10 dan 21 laki-laki dengan latar belakang sosial ekonomi yang heterogen.

\section{B. Fokus Penelitian}

Penelitian merupakan upaya pembatasan dimensi masalah atau gejala agar jelas ruang lingkupnya dan batasan yang akan di teliti, misalnya penelitian di sekolah sehingga kita dapat meneliti ruang 
lingkup yang ada didalam lingkungan sekolah.

\section{Prosedur Penelitian}

Sesuai dengan kaidah penelitian tindakan kelas (PTK) maka dalam penelitian ini disusun langkah-langkah kegiatan yang mengandung komponen utama PTK yaitu: perencanaan, pelaksanaan, observasi dan refleksi yang dibagi menjadi beberapa siklus.

Berikut ini Arikunto dalam Suyadi (2011:50) memberikan gambaran keempat langkah dalam PTK.

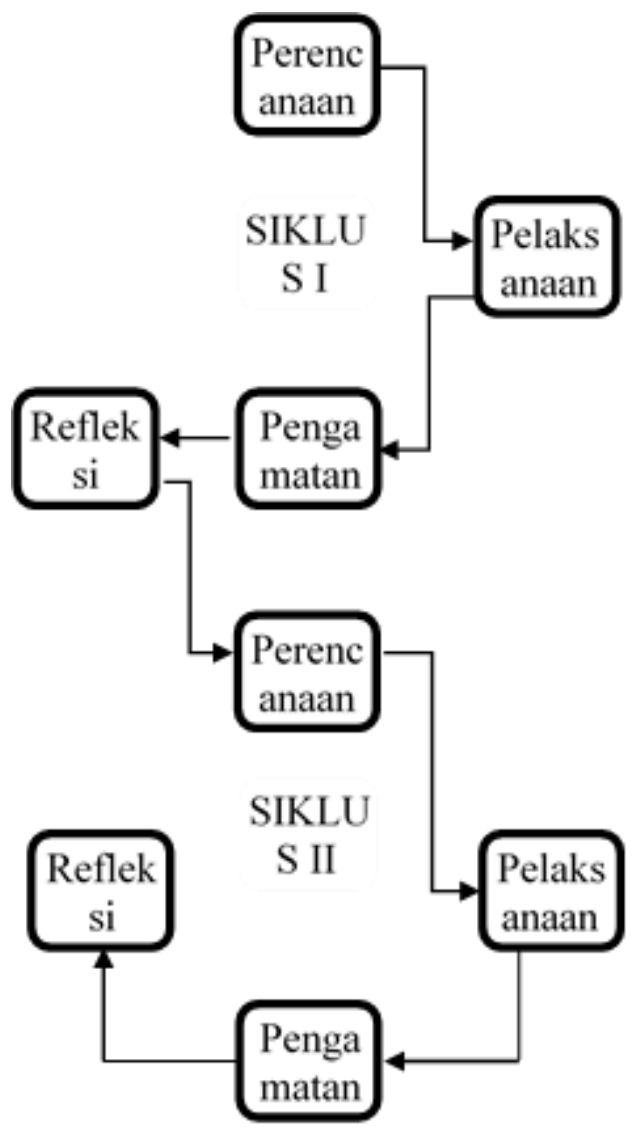

Gambar 2.Skema tahapan pelaksanaan penelitian tindakan kelas (PTK)
Secara lebih rinci langkah-langkah yang dilakukan dalam pelaksanaan penelitian tindakan ini dapat dijabarkan sebagai berikut :

Gambaran Umum Siklus I

1. Tahap perencanan

Langkah pertama yang dilakukan dalam suatu penelitian tindakan kelas adalah melakukan perencanaan secara matang dan telliti. Dalam perencanaan PTK, terdapat tiga kegiatan dasar yaitu: identifikasi masalah, merumuskan masalah, dan pemecahan masalah. Dan adapun langkah-langkah yang dilakukan dalam tahap perencanaan ini adalah sebagai berikut:

a) Menelaah kurikulum SMA dan sederajat kelas XII semester I mata pelajaran Sosiologi,

b) Memilih pokok bahasan perubahan Sosial

c) Menyusun rencana pelaksanaan pembelajaran (RPP),

d) Membuat skenario pembelajaran untuk melaksanakan tindakan dengan menggunakan metode pembelajaran Team Acclerated insctruction.

e) Membuat instrument penelitian berupa hasil tes belajar untuk melakukan evaluasi disetiap akhir siklus,

f) Membuat lembar observasi untuk melihat bagaimana kondisi atau keadaan 
siswa di kelas saat proses mengajar berlangsung selalu menggunakan metode pembelajaran Team Accelerated instruction. Menyediakan atau menyiapkan media/alat bantu yang akan digunakan dalam pembelajaran,

g) Membuat alat evaluasi berupa soal-soal yang disusun berdasarakan materi-materi yang telah diajarkan.

\section{Tahap pelaksanaan}

Tahap kedua dari suatu penelitian tindakan kelas adalah pelaksanaan. Pelaksanaan adalah menerapkan apa yang telah direncanakan pada tahap satu, yaitu bertindak di kelas. Pada tahap pelaksanaan, tindakan harus sesuai dengan rencana, dan harus terkesan alamiah dan tanpa rekayasa.

Pada saat pelaksanan tindakan untuk siklus I, yang pertama dilakukan peneliti adalah menjelaskan tujuan yang ingin di capai untuk materi pelajaran pada hari itu. Adapun kegiatan yang dilakukan pada tahap pelaksanaan adalah sebagai berikut:

a). Mengidentifikasi kesiapan siswa untuk mengikuti mata pelajaran.

b) Membahas materi pelajaran melalui pendekatan model pembelajaran Cooperative c) Memberikan kesempatan kepada siswa untuk menyelesaikan masalah sesuai dengan strategi yang ia ketahui baik secara perorangan maupun dengan kerja kelompok.

d) Memberikan umpan balik positif terhadap tanggapan siswa dan menekankan konsep dari materi yang diberikan.

e) Melakukan penugasan kepada siswa sesuai dengan bahan yang telah dikembangkan baik secara individual maupun kelompok.

f) Dengan memberikan motivasi dan menciptakan interaksi yang harmonis antara guru dan siswa, siswa diarahkan untuk menyelesaikan masalah/soal.

g) Mencatat semua kejadian yang di anggap penting selama kegiatan proses belajar mengajar berlangsung dalam lembar observasi.

h) Pada akhir siklus diberikan tes dari materi yang diajarkan.

3. Tahap observasi (pengamatan) Tahap ketiga dalam penelitian tindakan kelas adalah observasi.Supardi (dalam Suyadi (2011:63) menyatakan bahwa observasi yang dimaksud pada tahap ke III adalah pengumpulan data. Dengan kata 
lain, observasi adalah alat untuk memotret seberapa jauh efek tindakan telah mencapai sasaran. Pada langkah ini, harus diuraikan jenis data yang dikumpulkan, cara mengumpulkan, dan alat atau instumen pengumpulan data.

Pada tahap observasi ini di laksanakan observasi terhadap pelaksanaan tindakan dengan menggunakan lembar observasi yang telah dibuat serta melaksanakan observasi dengan melihat:

a. Siswa yang hadir

b. Banyaknya siswa yang memperhatikan penjelasan materi pelajaran

C. Siswa yang mengajukan pertanyaan dan tanggapan

d. Siswa yang dapat menjawab pertanyaan dengan benar

e. Siswa yang aktif dalam kelompoknya

f. Banyaknya kelompok yang melakukan diskusi yang baik

g. Siswa yang membantu membimbing temannya

h. Siswa yang bertanya pada kelompok lain

i. Kelompok yang dapat menyelesaikan tugas atau soal dengan benar

j. Siswa yang melakukan kegiatan lain pada saat proses pembelajaran berlangsung.

4. Tahap refleksi
Tahap terakhir dalam suatu penelitian tindakan kelas adalah refleksi (reflecting). Refleksi adalah kegiatan untuk mengemukakan kembali apa yang telah dilakukan.

Hasil yang diperoleh dari pengamatan terhadap tiap-tiap kelompok dipelajari dan diteliti, baik yang bersifat kualitatif dengan membuat catatan-catatan yang berhubungan dengan hal-hal yang dialami siswa selama mengikuti pembelajaran dengan menggunakan pendekatan metode pembelajaran Team Accelerated Instruction, maupun yang bersifat kuantitatif yaitu dengan mengamati hasil yang di peroleh dari tes hasil belajar siklus 1. Dari hasil ini akan di ambil tindakan-tindakan yang tepat, sebagai acuan bagi peneliti untuk merencanakan siklus berikutnya.

Gambaran umum siklus II

Pada prinsipnya kegiatan dalam siklus II ini relatif sama dengan siklus I. Siklus II merupakan pengulangan langkah kerja siklus sebelumnya yang telah mengalami perbaikan dan pengembangan yang di sesuaikan dengan hasil refleksi dari siklus I. Jadi antara siklus yang satu dengan yang lain tidak akan pernah sama, meskipun melalui tahap-tahap yang sama. Kegiatan-kegiatan dalam siklus ini dilakukan secara spiral yang 
memungkinkan terjadinya siklus-siklus yang lebih kecil dimana tiap siklus kecil tersebut adalah perbaikan dari siklus sebelumnya. Siklus kedua berlangsung selama 4 kali pertemuan, dengan rincian : pertemuan pertama, kedua, dan ketiga penyajian dan pada pertemuan keempat dilakukan tes akhir siklus II serta pengisian angket tanggapan siswa.

\section{Teknik Pengumpulan Data}

Cara pengambilan data dalam penelitian ini adalah sebagai berikut :

a. Data hasil belajar diperoleh dengan memberikan tes kepada siswa.

b. Data tentang situasi pembelajaran saat pelaksanaan tindakan diperoleh melalui hasil observasi.

Adapun teknik pengumpulan data pada penilitian ini adalah sebagai berikut:

a. Observasi yaitu teknik penelitian dengan mendatangi lokasi penelitian, mengadakan pengamatan secara langsung terhadap objek yang diteliti.

b. Interview yaitu mendapatkan data dengan mengadakan tanya jawab langsung dengan responden yaitu beberapa siswa SMA Negeri 1 Bontomarannu.

c. Angket yaitu sejumlah pertanyaan tertulis yang di gunakan untuk memperoleh informasi dari

responden tentang hal-hal yang ingin diketahui.

d. Dokumentasi yaitu penulis mengumpulkan bahan yang berhubungan dengan materi kajian berupa dokumen tertulis tentang nilai ujian siswa.

\section{E. Teknik Analisis Data}

Data yang terkumpul dianalisis dengan cara kualitatif dan kuantitatif. Untuk data tentang hasil tes dianalisis secara kuantitatif dengan menggunakan analisis deskriptif yang terdiri atas rata-rata (mean), rentang (range), median, standar deviasi, nilai maksimum, dan nilai minimum yang diperoleh siswa pada tiap siklus. Untuk jenis analisis kualitatif, data yang di gunakan adalah ketuntasan yanng merupakan hasil observasi. Kriteria yang di gunakan untuk menentukan kategori keberhasilan dalam penilaian mengacu pada kriteria standar yang berlaku di SMA Negeri 1 Bontomarannu yaitu hasil keputusan Direktorat Jenderal Pendidikan Dasar dan Menengah No. 288/C3/MN/99 (Depdikbud 1994).

Tabel 3.1 :Kategorisasi Standar Berdasarkan Ketetapan Direktorat Jenderal Pendidikan Dasar dan Menengah 


\begin{tabular}{|l|l|}
\hline Nilai & Kategori \\
\hline $0-34$ & Sangat rendah \\
\hline $34-54$ & Rendah \\
\hline $55-64$ & Sedang \\
\hline $74-84$ & Tinggi \\
\hline $85-100$ & Sangat tinggi \\
\hline
\end{tabular}

Pada bab ini, akan dibahas hasil-hasil penelitian yang memperlihatkan hasil belajar sosiologi siswa kelas XIISMA Negeri 1 Bontomarannu melalui pengimplementasian metode pembelajaran Team Accelerated Intruction dari Siklus I ke Siklus II dengan menggunakan analisis kualitatif yaitu data tentang hasil observasi, sedangkan data tentang hasil belajar siswa dianalisis secara kuantitatif dengan menggunakan statistik deskriptif yaitu skor rata-rata, standar deviasi, frekuensi, dan persentase nilai terendah dan nilai tertinggi yang dicapai siswa setiap Siklus.

\section{Paparan Data Siklus Pertama}

a. Tahap Perencanaan

1) Menyiapkan skenario pembelajaran dengan menggunakan metode pembelajaran team accelerated intruction pada pokok bahasan perubahan sosial setiap pertemuan.
2) Membuat dan menyusun alat evaluasi.

3) Menyiapkan pedoman observasi.

b. Tahap Pelaksaanaan Tindakan

1) Mengecek kehadiran siswa.

2) Guru menjelaskan tujuan pembelajaran, menjelaskan logistik yang dibutuhkan, mengajukan fenomena atau demonstrasi atau cerita untuk memunculkan masalah, memotivasi siswa untuk terlibat dalam proses pembelajaran. (tahap 1).

3) Guru membantu siswa mendefinisikan dan mengorganisasikan tugas belajar yang berhubungan dengan materi tersebut (Tahap 2).

4) Guru mendorong siswa untuk mengumpulkan informasi yang sesuai, melaksanakan eksperimen,untukk mendapatkan penjelasan materi. (Tahap 3).

5) Guru membantu siswa dalam merencanakan dan menyiapkan karya yang sesuai seperti laporan dan model yang membantu mereka untuk 
berbagi tugas dengan temannya. (tahap 4).

6) Guru membantu siswa untuk melakukan refleksi atau evaluasi terhadap penyelidikan mereka dan proses-proses yang mereka gunakan. (tahap 5).

7) Guru menyampaikan materi yang akan dibahas pada pertemuan selanjutnya.

c. Tahap Observasi dan Evaluasi

1. Hasil observasi

- Pada pertemuan I

Pada pertemuan I tercatat aktifitas siswa yang terjadi selama proses belajar mengajar berlangsung. Aktifitas tersebut diperoleh dari lembar observasi yang tercatat pada pertemuan I, yaitu:

1) Frekuensi kehadiran siswa pada pertemuan I sebanyak 31 orang dari 31 siswa. Siswa yang mengikuti dengan cermat proses pembelajaran. Pada pertemuan ini umumnya siswa merasa tegang dan pasif dengan pendekatan pembelajaran yang digunakan utamanya pada saat pemberian tugas kinerja.

2) Siswa yang memperhatikan pada saat proses pembelajaran sebanyak 16 orang masih tergolong kurang.
3) Siswa yang melakukan aktifitas negatif selama proses pembelajaran berlangsung sebanyak 6 orang. Hal ini terlihat dari tingkah laku siswa yang bermacam-macam, ada yang mengerjakan tugas pelajaran lain, ada yang minta izin keluar dan yang mengganggu temannya yang sedang belajar.

4) Siswa yang mengerjakan pekerjaan rumah (PR) sebanyak 24 orang.

5) Siswa yang piawai dalam mempresentasekan materinya sebanyak 6 orang.

6) Siswa yang berani mengajukan pendapat sebanyak 3 orang.

7) Siswa yang masih butuh bimbingan sebanyak 10 orang.

8) Siswa yang masih pasih dalam proses pembelajaran sebanyak 5 orang

- Pada pertemuan II

Pada pertemuan II tercatat aktifitas yang terjadi selama proses belajar mengajar berlangsung. Aktifitas siswa tersebut diperoleh dari lembar observasi yang tercatat pada pertemuan II, yaitu:

1) Frekuensi kehadiran siswa pada pertemuan II sebanyak 19 orang dari 31 siswa. Siswa yang 
mengikuti dengan cermat proses pembelajaran sebagian besar mulai menyenangi proses pembelajaran yang berlangsung.

2) Siswa yang memperhatikan pada saat proses pembelajaran sebanyak 16 orang. Hal ini menandakan adanya perhatian siswa terhadap model pembelajaran yang digunakan.

3) Siswa yang melakukan aktifitas negatif selama proses pembelajaran berlangsung sebanyak 2 orang. Hal ini terlihat dari tingkah laku siswa yang bermacam-macam, ada yang mengerjakan tugas pelajaran lain, ada yang minta izin keluar dan yang mengganggu temannya yang sedang belajar.

4) Siswa yang mengerjakan pekerjaan rumah sebanyak 25 orang.

5) Siswa yang piawai dalam mempresentasekan hasil wacana dengan pasangannya sebanyak 12 orang.

6) Siswa yang berani mengajukan pendapat sebanyak 5 orang.

7) Siswa yang masih butuh bimbingan sebanyak 10 orang
8) Siswa yang masih pasif dalam proses pembelajaran sebanyak 7 orang.

- Pada pertemuan III

Pada pertemuan III tercatat aktifitas yang terjadi selama proses belajar mengajar berlangsung. Aktifitas siswa tersebut diperoleh dari lembar observasi yang tercatat pada pertemuan III, yaitu:

1) Frekuensi kehadiran siswa pada pertemuan III sebanyak 18 orang dari 31 siswa yang mengikuti dengan cermat proses pembelajaran

2) Siswa yang memperhatikan pada saat proses pembelajaran sebanyak 18 orang. Hal ini menadakan adanya peningkatan perhatian siswa terhadap pembelajaran.

3) Siswa yang melakukan aktifitas negatif selama proses pembelajaran berlangsung sebanyak 3 orang. Hal ini menandakan berkurangnya siswa yang melakukan hal negatif seperti ribut, mengerjakan tugas lain disbanding pertemuan sebelumnya.

4) Siswa yang mengerjakan pekerjaan rumah (PR) sebanyak 25 orang. Hal ini menandakan 
adanya peningkatan siswa yang memperhatikan PR.

5) Siswa yang piawai dalam mempresentasekan hasil wacana dengan pasangannya sebanyak 10 orang.

6) Siswa yang berani mengajukan pendapat sebanyak 7 orang.

7) Siswa yang masih butuh bimbingan sebanyak 5 orang.

8) Siswa yang masih pasif dalam proses pembelajaran sebanyak 5 orang

- Pertemuan IV

Memberikan tes hasil belajar sosiologi siklus I.

Seperti yang dijelaskan sebelumnya bahwa data diperoleh dari hasil evaluasi dan observasi dianalisis secara kuantitatif dan kualitatif.

\section{Hasil Evaluasi}

\section{Analisis Kuantitatif}

\section{a. Deskripsi Hasil Tes Siklus I}

Pada Siklus I ini, dilaksanakan tes hasil belajar yang berbentuk uraian setelah selesai penyajian materi untuk Siklus I. Adapun analisis deskriptif skor hasil belajar pada siklus I disajikan pada tabel 4.1 berikut ini:

Tabel 4.1. Statistik Skor Hasil Tes Siswa Pada Siklus I

\begin{tabular}{|c|c|}
\hline Statistik & Nilai Statistik \\
\hline Subjek & 31 \\
\hline Skor Ideal & 100 \\
\hline Skor Tertinggi & 85 \\
\hline Skor Terendah & 50 \\
\hline Skor Rata-rata & 64,3 \\
\hline Rentang Skor & 50 \\
\hline Standar deviasi & 11,9 \\
\hline
\end{tabular}

bahwa skor rata-rata (mean) hasil belajar sosiologi setelah diimplementasikan metode pembelajaran kooperatif tipe team accelerated intruction pada siswa kelas XII SMA Negeri 1 Bontomarannu adalah 64,3 dari skor ideal yang mungkin dicapai adalah 100. Sedangkan secara individual skor yang dicapai siswa pada penerapan ini tersebar dengan skor tertinggi 85 dan skor terendah 50 dari skor tertinggi yang mungkin dicapai 100 dan skor terendah yang mungkin dicapai 0 , dengan rentang skor 50.

Setelah skor hasil tes siswa dikelompokkan ke dalam lima kategori, maka diperoleh distribusi frekuensi. 
Bontomarannu pada siklus I di sajikan

\begin{tabular}{|c|c|c|c|}
\hline $\begin{array}{l}\text { Inter } \\
\text { val } \\
\text { Skor }\end{array}$ & Kategori & $\begin{array}{l}\text { Fre } \\
\text { kue } \\
\text { nsi }\end{array}$ & Persentase $(\%)$ \\
\hline $\begin{array}{l}0- \\
34\end{array}$ & $\begin{array}{l}\text { Sangat } \\
\text { Rendah }\end{array}$ & 0 & 0,00 \\
\hline $\begin{array}{c}35- \\
54\end{array}$ & Rendah & 6 & $19,35 \%$ \\
\hline $\begin{array}{c}55- \\
64 \\
\end{array}$ & Sedang & 14 & $45,16 \%$ \\
\hline $\begin{array}{c}65- \\
84\end{array}$ & Tinggi & 9 & $29,03 \%$ \\
\hline $\begin{array}{l}85- \\
100\end{array}$ & $\begin{array}{l}\text { Sangat } \\
\text { Tinggi }\end{array}$ & 2 & 6,45 \\
\hline \multicolumn{2}{|c|}{ Jumlah } & 31 & $100 \%$ \\
\hline
\end{tabular}

Dari Tabel 4.1 dan 4.2

menunjukkan bahwa tidak ada siswa yang berada pada kategori sangat rendah, 19,35\% siswa berada pada kategori rendah, 45,16\% berada pada kategori sedang, $29,03 \%$ berada pada kategori tinggi, dan 6,45 siswa berada dalam kategori sangat tinggi.

Berikut ini adalah gambar grafik diagram batang dari hasil belajar dari siklus I sebagai berikut:

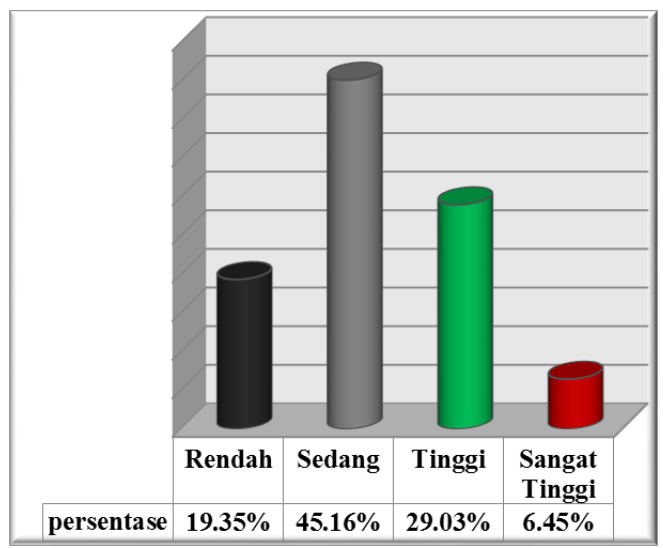

Analisis deskriptif ketuntasan belajar siswa kelas XII SMA Negeri 1

pada tabel 4.3 berikut ini:

Tabel 4.3 Deskriptif ketuntasan hasil belajar siswa pada siklus I

\begin{tabular}{|l|l|l|l|}
\hline Skor & $\begin{array}{l}\text { Kategor } \\
\text { i }\end{array}$ & $\begin{array}{l}\text { Frekuen } \\
\text { si }\end{array}$ & $\begin{array}{l}\text { Persenta } \\
\text { se } \%\end{array}$ \\
\hline $0-64$ & $\begin{array}{l}\text { Tidak } \\
\text { tuntas }\end{array}$ & 20 & $64,51 \%$ \\
\hline $\begin{array}{l}65- \\
100\end{array}$ & Tuntas & 11 & $35,48 \%$ \\
\hline $\begin{array}{l}\text { Jumla } \\
\text { h }\end{array}$ & & 31 & $100 \%$ \\
\hline
\end{tabular}

Dari tabel 4.3 di atas, menunjukkan bahwa terdapat 20 atau $64,51 \%$ dari 31 siswa termasuk ke dalam kategori tidak tuntas dan 11 Orang atau $35,48 \%$ siswa yang termasuk dalam kategori tuntas.

\section{Paparan Data Siklus Kedua}

a. Tahap perencanaan

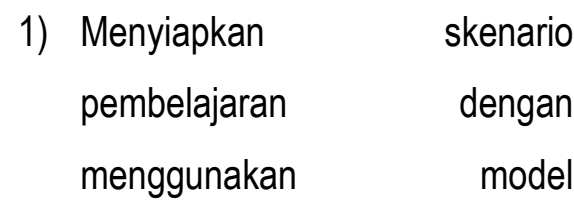
pembelajaran berbasis masalah pada pokok bahasan perilaku menyimpang setiap pertemuan.

2) Membuat dan menyusun alat evaluasi.

3) Menyiapkan pedoman observasi. 
b. Tahap Pelaksaanaan Tindakan

1) Mengecek kehadiran siswa.

2) Guru menjelaskan tujuan pembelajaran, menjelaskan logistik yang dibutuhkan, mengajukan fenomena atau demonstrasi atau cerita untuk memunculkan masalah, memotivasi siswa untuk terlibat dalam pemecahan masalah yang dipilihnya. (tahap 1).

3) Guru membantu siswa mendefinisikan dan mengorganisasikan tugas belajar yang berhubungan dengan masalah tersebut (Tahap 2).

4) Guru mendorong siswa untuk mengumpulkan informasi yang sesuai, melaksanakan eksperimen, untuk mendapatkan penjelasan pemecahan masalah. (Tahap 3).

5) Guru membantu siswa dalam merencanakan dan menyiapkan karya yang sesuai seperti laporandan model yang membantu mereka untuk berbagi tugas dengan temannya. (tahap 4).

6) Guru membantu siswa untuk melakukan refleksi atau evaluasi terhadap penyelidikan mereka dan proses-proses yang mereka gunakan. (tahap 5).

7) Guru menyampaikan materi yang akan dibahas pada pertemuan selanjutnya.

c. Tahap observasi dan evaluasi

1. Tahap observasi

- Pada pertemuan V

Pada pertemuan $\mathrm{V}$ tercatat aktifitas siswa yang terjadi selama proses belajar mengajar berlangsung Aktifitas tersebut diperoleh dari lembar observasi yang tercatat pada pertemuan V, yaitu:

1) Frekuensi kehadiran siswa pada pertemuan $\mathrm{V}$ sebanyak 29 orang dari 31 siswa. Hal ini menandakan perhatian siswa terhadap proses pembelajaran.

2) Siswa yang memperhatikan pada saat proses pembelajaran sebanyak 17 orang. Hal ini menandakan adanya peningkatan banyaknya siswa yang memperhatikan proses pembelajaran disetiap pertemuan

3) Siswa yang melakukan aktifitas negatif selama proses pembelajaran berlangsung sebanyak 2 orang. Hal ini menandakan semakin 
berkurangnya siswa yang

melakukan hal negatif seperti ribu, mengerjakan tugas lain dll.

4) Siswa yang mengerjakan pekerjaan rumah sebanyak 27 orang.

5) Siswa yang piawai dalam mempresentasekan hasil wacananya dengan pasangannya sebanyak 20 orang.

6) Siswa yang berani mengajukan pendapat sebanyak 7 orang.

7) Siswa yang masih butuh bimbingan sebanyak 5 orang.

8) Siswa yang masih pasif dalam proses pembelajaran sebanyak 8 Orang

- Pada pertemuan VI

Pada pertemuan VI tercatat aktifitas siswa yang terjadi selama proses belajar mengajar berlangsung. Aktifitas tersebut diperoleh dari lembar observasi yang tercatat pada pertemuan $\mathrm{VI}$, yaitu:

1) Frekuensi kehadiran siswa pada pertemuan VI sebanyak 29 orang dari 31 siswa. Hal ini menandakakan perhatian saiswa pada proses pembelajaran.

2) Siswa yang memperhatikan pada saat proses pembelajaran sebanyak 19 orang. Hal ini menandakan adanya peningkatan banyaknya siswa yang memperhatikan proses pembelajaran.

3) Siswa yang melakukan aktifitas negatif selama proses pembelajaran berlangsung sebanyak 2 orang. Hal ini menandakan semakin berkurangnya siswa yang melakukan hal negatif seperti rebut, mengerjakan tugas lain dll.

4) Siswa yang menegrjakan pekerjaan rumah (PR) sebanyak 25 orang.

5) Siswa yang piawai dalam mempresentasekan hasil wacananya dengan pasangannya sebanyak 21 orang.

6) Siswa yang berani mengajukan pendapat sebanyak 10 orang.

7) Siswa yang masih butuh bimbingan sebanyak 4 orang.

8) Siswa yang masih pasif dalam proses pembelajaran sebanyak 7 orang

- Pada pertemuan VII

Pada pertemuan VII tercatat aktifitas siswa yang terjadi selama proses belajar mengajar berlangsung. Aktifitas tersebut 
diperoleh dari lembar observasi yang tercatat pada pertemuan VII, yaitu:

1) Frekuensi kehadiran siswa pada pertemuan VII sebanyak 31 orang dari 31 siswa. Hal ini menandakakan perhatian saiswa pada proses pembelajaran.

2) Siswa yang memperhatikan pada saat proses pembelajaran sebanyak 21 orang. Hal ini menandakan adanya peningkatan banyaknya siswa yang memperhatikan proses pembelajaran

3) Tidak ada siswa yang melakukan aktifitas negatif selama proses pembelajaran berlangsung. Hal ini menandakan perhatian siswa terhadap proses pembelajaran yang sedang berlangsung sehingga tidak ada siswa lagi yang melakukan hal-ha negatip seperti ribut, mengerjakan tugas lain dII.

4) Siswa yang mengerjakan pekerjaan rumah (PR) sebanyak 26 orang.

5) Siswa yang piawai dalam mempresentasekan hasil wacana dengan pasangannya sebanyak 22 orang.
6) Siswa yang berani mengajukan pendapat sebanyak 11 orang.

7) Siswa yang masih butuh bimbingan sebanyak 3 orang.

8) Siswa yang masih pasif dalam proses pembelajaran sebanyak 5 orang

- Pertemuan VIII

Memberikan tes hasil belajar sosiologi siklus II dan setelah siswa selesai mengerjakan tes, peneliti membagikan angket.

Seperti yang dijelaskan
sebelumnya bahwa data yang
diperoleh dari hasil evaluasi dan
observasi dianalisis secara
kuantitatif dan kualitatif.

2. Hasil Evaluasi

a. Deskripsi Hasil Tes Siklus II

Analisis terhadap skor hasil belajar siswa setelah diimplementasikan metode pembelajaran kooperatif team accelerated intructionselama berlangsungnya Siklus ॥ dapat dilihat pada Tabel 


\begin{tabular}{|l|l|}
\hline Statistik & Nilai Statistik \\
\hline Subjek & 31 \\
\hline Skor Ideal & 100 \\
\hline Skor Tertinggi & 96 \\
\hline Skor Terendah & 60 \\
\hline Skor Rata-rata & 77,38 \\
\hline Rentang Skor & 50 \\
\hline Standar deviasi & 61,7 \\
\hline
\end{tabular}

\begin{tabular}{|l|l|l|l|}
\hline Interval Skor & Kategori & $\begin{array}{l}\text { Frekuens } \\
\mathrm{i}\end{array}$ & $\begin{array}{l}\text { Persen } \\
\text { tase } \\
(\%)\end{array}$ \\
\hline $0-34$ & $\begin{array}{l}\text { Sangat } \\
\text { Rendah }\end{array}$ & 0 & 0,00 \\
\hline $35-54$ & $\begin{array}{l}\text { Rendah } \\
55-64\end{array}$ & 0 & 0,00 \\
\hline $65-84$ & Sedang & 3 & 9,67 \\
\hline $85-100$ & Singgi & 19 & $61,29 \%$ \\
\hline Jumlah & & 31 & $29,03 \%$ \\
\hline
\end{tabular}

Tabel. 4.5 Distribusi Frekuensi dan

Tabel. 4.4 Statistik Skor Hasil Tes Siswa pada Siklus II

Dari Tabel. 4.4 menunjukkan bahwa skor rata-rata (mean) hasil belajar sosiologi setelah diimplementasikan metode pembelajaran team accelerated intruction pada siswa kelas XIISMA Negeri 1 Bontomarannu adalah 77,38 dari skor ideal yang mungkin dicapai adalah 100 . Sedangkan secara individual skor yang dicapai siswa pada penerapan ini tersebar dengan skor tertinggi 96 dan skor terendah 60 dari skor tertinggi yang mungkin dicapai 100 dan skor terendah yang mungkin dicapai 0, dengan rentang skor 50 .

Setelah skor hasil tes siswa dikelompokkan ke dalam lima kategori, maka diperoleh distribusi frekuensi dan persentase sebagai berikut: 


\begin{tabular}{|c|c|c|c|c|c|c|}
\hline \multirow{2}{*}{$\mathrm{N}$} & \multirow{2}{*}{$\begin{array}{l}\text { Komponen yang } \\
\text { diamati }\end{array}$} & \multicolumn{5}{|c|}{ Siklus II } \\
\hline & & 1 & 2 & 3 & $\begin{array}{l}\text { Rata- } \\
\text { rata }\end{array}$ & $\%$ \\
\hline 1 & $\begin{array}{l}\text { Banyaknya siswa yang } \\
\text { hadir pada saat proses } \\
\text { pembelajaran } \\
\text { berlangsung. }\end{array}$ & 29 & $\begin{array}{l}2 \\
9\end{array}$ & 1 & 29,66 & 95,67 \\
\hline 2 & $\begin{array}{l}\text { Siswa yang } \\
\text { memperhatikan } \\
\text { penjelasan guru. }\end{array}$ & 17 & $\begin{array}{l}1 \\
9\end{array}$ & $\begin{array}{l}2 \\
1\end{array}$ & 19 & 61,29 \\
\hline 3 & $\begin{array}{l}\text { Siswa yang } \\
\text { melakukan kegiatan } \\
\text { lain pada saat proses } \\
\text { pembelajaran. }\end{array}$ & 2 & - & 2 & 1,3 & 4,19 \\
\hline 4 & $\begin{array}{l}\text { Siswa yang } \\
\text { mengerjakan } \\
\text { pekerjaan rumah (PR). }\end{array}$ & 27 & $\begin{array}{l}2 \\
5\end{array}$ & $\begin{array}{l}2 \\
6\end{array}$ & 26 & 83,87 \\
\hline 5 & $\begin{array}{l}\text { Siswa yang piawai } \\
\text { dalam } \\
\text { mempresentasikan } \\
\text { hasil wacana dengan } \\
\text { pasangannya. }\end{array}$ & 20 & $\begin{array}{l}2 \\
1\end{array}$ & $\begin{array}{l}2 \\
2\end{array}$ & 21 & 67,74 \\
\hline 6 & $\begin{array}{l}\text { Siswa yang berani } \\
\text { mengajukan pendapat }\end{array}$ & 7 & $\begin{array}{l}1 \\
0\end{array}$ & $\begin{array}{l}1 \\
1\end{array}$ & 9,3 & 3,0 \\
\hline 7 & $\begin{array}{l}\text { Siswa yang masih } \\
\text { butuh bimbingan }\end{array}$ & 5 & 4 & 3 & 4 & 12,90 \\
\hline 8 & $\begin{array}{l}\begin{array}{l}\text { Siswa yang masih } \\
\text { pasif }\end{array} \\
\end{array}$ & 8 & 7 & 5 & 6,7 & 21,61 \\
\hline
\end{tabular}

Dari hasil analisis deskriptif di atas menunjukkan bahwa hasil belajar sosiologi siswa Kelas XII SMAN 1 Bontomarannu setelah pengimplementasian metode pembelajaran team accelerated mengalami peningkatan. Hal ini dikatakan dengan melihat peningkatan skor rata-rata yang diperoleh siswa dari 64,3 pada Siklus I menjadi 77,38 pada Siklus II.
2. Analisis Kualitatif

a. Hasil Observasi Siswa

1) Siklus I

Pada Siklus I, keaktifan siswa dapat dilihat pada lembar observasi yang ditunjukkan pada tabel di bawah ini :

Tabel. 4.7 Keaktifan Siswa pada Siklus I Berdasarkan Tabel. 4.7 di atas, dapat dilihat bahwa hampir 100\% siswa hadir pada Siklus I yang dilaksanakan sebanyak empat kali pertemuan yaitu 73,22\%, $61,85 \%$ yang memperhatikan penjelasan guru, $13,70 \%$ yang melakukan kegiatan lain (ribut, ganggu teman sebangku dan main-main) pada saat proses pembelajaran, 91,48\%, siswa yang mengerjakan tugas pekerjaan rumah, $47,04 \%$ yang piawai dalam mempresentasikan hasil wacana dengan pasangannya, $18,52 \%$ yang berani mengajukan pendapat, 30,74 yang masih butuh bimbingan dan $24,81 \%$ yang masih pasif.

2) Siklus II

Pada Siklus II, keaktifan siswa dapat dilihat pada lembar observasi yang ditunjukkan pada tabel di bawah ini;

Tabel 4.8 Keaktifan Siswa pada Siklus II. Berdasarkan Tabel. 4.8 di atas, dapat dilihat bahwa hampir 100\% siswa hadir pada Siklus II yang dilaksanakan sebanyak empat kali pertemuan yaitu 
$95,67 \%, 61,29 \%$ yang memperhatikan penjelasan guru, 4,19\% yang melakukan kegiatan lain (ribut, ganggu teman sebangku dan main-main) pada saat proses pembelajaran, $83,87 \%$, siswa yang mengerjakan tugas pekerjaan rumah, $67,74 \%$ yang piawai dalam mempresentasikan hasil wacana dengan pasangannya, $3,0 \%$ yang berani mengajukan pendapat, $12,90 \%$ yang masih butuh bimbingan dan 21,61\% yang masih pasif.

\section{Refleksi terhadap Pelaksanaan Tindakan dalam Proses Belajar Mengajar Sosiologi}

Data yang di analisis pada bagian ini adalah data yang di peroleh dari hasil pengamatan dan tanggapan-tanggapan siswa.

\section{1) Refleksi Siklus I}

Pada siklus pertama ini hal-hal yang di catat adalah :

a) Pada pertemuan pertama terdapat beberapa siswa yang tidak memperhatikan pelajaran. Hal ini di tandai dengan mereka berbicara dengan teman-teman sebangkunya pada saat kegiatan pembelajaran berlangsung. Peneliti menduga bahwa semua ini disebabkan karena kurangnya minat baca siswa dan kurangnya proses sosialisasi dengan teman temannya.

b) Pada pertemuan selanjutnya, siswa laki-laki bertukar posisi tempat duduk dengan siswa perempuan, laki-laki berada di posisi tempat duduk depan agar tercipta suasana yang kondusif.

c) Banyak siswa yang tidak berani angkat tangan untuk naik mempresentasikan hasil wacana dengan pasangannya.

d) Dalam pembahasan materi, keaktifan siswa dalam mengemukakan pendapatdan menanyakan hal-hal yang masih kurang dimengerti, masih terlihat ragu-ragu karena takut salah. Namun demikian ada beberapa orang siswa yang terlihat antusias dalam berpendapat.

e) Kesalahan-kesalahan yang ditemukaan pada siswa yaitu dalam mengerjakan soal, umumnya di sebabkan siswa tidak menguasai pengetahuan prasyarat yang diperlukan, antara lain kurang memahami pelajaran atau materi yang telah di berikan sebelumnya,sehingga lambat dalam menyelesaikan soal-soal. 
Kendala utama dalam pelaksanaan siklus I karena kurangnya minat siswa dalam membaca dan kurangnya proses sosialisasi dengan teman-temanya. Oleh karena itu perlu upaya selanjutnya untuk memperbaikinya. Namun diakhir siklus ini interaksi siswa mulai sedikit meningkat terhadap penggunaan metode pembelajaran team accelerated intruction yang menunjukkan memberikan perubahan positif, hal ini dilihat dari refleksi di mana mereka mulai menyukai model pembelajaran team accelerated intruction, karena sudah dilatih untuk beberapa kali pertemuan,aktivitas yang dibentuk dalam metode pembelajaran team accelerated intruction mereka anggap sebagai wadah melatih diri untuk bekerja sama sehingga belajar bersama-sama di antara sesame pasangan. Selain itu, siswa dapat mandiri dalam memahami sub pokok bahasan yang dipelajari tanpa harus bergantung kepada guru sebagai salah satu sumber informasi.

Hasil refleksi tersebut menjadi dasar acuan dilanjutkan pelaksanaan tindakan ke siklus II dengan mengupayakan perbaikan melalui pembelajaran dengan metode pembelajaran team accelerated intruction, menekankankepada siswa menggunakan materi pelajaran yang telah dibaca untuk memecahkan masalah- masalah yang ada dengan berinteraksi dan saling percaya diri, terbuka dan rileks di antara anggota kelompok.

Pada siklus ini masih terdapat hal-hal yang perlu diperbaiki, diantaranya tentang mengefektifkan waktu dalam memberikan bimbingan secara langsung kepada siswa yang belum mengerti mengenai materi yang telah dibahas. Jika banyak siswa yang tidak mengerti maka akan memperlambat dan memperpanjang waktu pembahasan, sementara alokasi waktu sangat terbatas. Oleh karena itu masih perlu di adakan tindakan perbaikan pembelajaran pada siklus berikutnya.

\section{2) Refleksi Siklus II}

Pada siklus ke II ini hal-hal yang di catat adalah

a) Perhatian siswa dalam mengikuti pelajaran semakin baik dibandingkan dengan siklus sebelumnya. Hal ini ditandai dengan semakin banyaknya siswa yang piawai, percaya diridan berani apabila di berikan kesempatan mempresentasikan hasil wacana dengan pasangannya.

b) Dalam mengerjakan soal-soal masih ditemukan hal-hal yang masih perlu di mantapkan. Misalnya ketepatan dalam 
menjawab soalbelum sempurna, langkah - langkah berdiskusi masih ada yang belum mengerti, dan masih banyak yang lainnya yang masih perlu diperbaiki.

c) Minat baca siswa semakin bertambah dan mereka menganggap bahwa metode ini melatih diri untuk saling bekerja sama dengan teman sebangku dan saling bersosialisasi jika ada kendala dalam proses pembelajaran.

d) Karena terkendala dengan waktu maka siswa yang masih belum terlalu paham dengan materi pembelajaran maka diberi bimbingan di luar jam pelajaran yaitu bisa menanyakan kembali dan siswa yang termasuk kategori pintar, ikut membantu temantemannya yang belum paham.

e) Sikap siswa sudah menunjukkan antusias dalam mengikuti pelajaran bahkan sebagian siswa senang melakukan diskusi berpasangan karena dapat menambahkan informasi dan siswa cepat memahami materi karena siswa sendiri yang berpikir/berimajinasi dan mencari sendiri kata kunci dari wacana kemudian mempresentasikan dengan kalimat sendiri, yang penting maksudnya sama serta belajarakan lebih baik apabila didukung oleh lingkungan kondusif.

f) Frekuensi kehadiran siswa selama mengikuti proses belajar mengajar sampai akhir pertemuan siklus II menggambarkan bahwa minat baca dan motivasi belajar siswa mengalami peningkatan, siswa sudah memperlihatkan keberanian yaitu maju di depan kelas untuk mempresentasikan tanpa di tunjuk serta berani mengungkapkan pendapat dan bertanya jika ada hal yang belum dimengerti tanpa ada rasa takut salah.

Secara umum bentuk tindakan yang dilakukan pada siklus ini dapat membawa siswa kearah perubahan sikap yang lebih mendukung berlangsungnya kegiatan pembelajaran. Pada siklus ini, siswa lebih antusias dalam belajar. Oleh karena itu, bentuk tindakan yang di lakukan pada siklus ini memberikan hasil yang lebih baik dari pada tindakan pada siklus sebelumnya. Walaupun Dari siklus I sampai siklus II masih ada beberapa orang siswa yang menurut pengamatan peneliti 
sangat pasif baik di tinjau dari keaktifan dalam proses belajar mengajar maupun dari hasil tes yang di peroleh masih kurang, sehingga peneliti ingin mengetahui penyebab dari semua itu, maka peneliti mengadakan pendekatan langsung dengan siswa yang bersangkutan dan cerita - cerita dengan beberapa guru dan siswa, maka peneliti menyimpulkan bahwa ada beberapa faktor penyebabnya yaitu karena ketidaksempurnaan fisik dan faktor kenakalan.

\section{Refleksi Umum (Tanggapan Siswa)}

Dari hasil analisis terhadap refleksi atau tanggapan siswa, dapat disimpulkan ke dalam kategori sebagai berikut:

\section{a. Pendapat Siswa terhadap}

\section{Pelajaran Sosiologi}

Pada umumnya siswa kurang menyukai pelajaran sosiologi, menurut mereka sosiologi adalah salah satu pelajaran yang sangat sulit untuk dipelajari dan membosankan tapi mereka juga sadar bahwa pelajaran sosiologi penting untuk dipelajari dan dikuasai karena berguna dalam kehidupan sehari - hari ataupun bidang lainnya. Adapun siswa yang beranggapan bahwa belajar sosiologi dapat mengasah otak dan melatih siswa untuk berpikir memecahkan masalah dan menyenangkan karena membahas tentang masalah yang ada di dalam masyarakat.Bukan hanya teori tapi pengaplikasian dalam kehidupan sehari hari memberikan pengaruh positif. Namun tidak dapat juga dipungkiri sebagian siswa ada juga yang berpendapat bahwa sosiologi adalah pelajaran yang gampanggampang susah. Beberapa siswa berpendapat bahwa sosiologi membutuhkan banyak hafalan terutama teori-teori.

b. Pendapat Siswa terhadap Metode Pembelajaran Team

\section{Accelerated Intruction}

Secara umum siswa berpendapat bahwa pengajaran sosiologi dengan menggunakan metode pembelajaran team accelerated intruction sangat membantu mereka untuk lebih memahami konsep sosiologi karena dengan menggunakan metode tersebut maka siswa lebih bebas berpendapat dan dapat bertukar pendapat tentang apa yang mereka ketahui tentang sub pokok bahasan masing-masing. Hal ini, siswa menanggapi secara positif, mereka menganggap bahwa pembelajaran metode team accelerated intruction selain mengajarkan mereka untuk bersosialisasi dengan teman pasangan masing-masing mereka juga diajarkan untuk saling membantu 
pasangannya, dan mereka juga lebih bersemangat dalam belajar agar kelompok mereka menjadi yang terbaik. Serta alasan lain muncul yaitu siswa senang dengan metode pembelajaran yang diterapkan peneliti, yang dianggap lebih rileks dan melatih bekerja sama serta memiliki rasa percaya diri sehingga mereka lebih termotivasi untuk belajar sosiologi.

\section{c. Saran - saran dari Siswa}

1. Guru harus lebih tegas lagi, baik dalam menyampaikan materi maupun menghukum siswa yang ribut, yang tidak menulis atau fotocopy, yang tidak serius dalam belajar dan yang tidak mengerjakan tugas dan PR serta volume suara ditambah.

2. Guru sebaiknya memberikan tugas lebih banyak lagi supaya mereka lebih giat lagi dalam belajar.

\section{PEMBAHASAN}

Berdasarkan hasil penelitian yang telah dianalisis dapat dilihat bahwa pada siklus I selama kegiatan pembelajaran berlangsung, terlihat bahwa siswa sedikit termotivasi untuk mengikuti pembelajaran karena metode pembelajaran yang diberikan tergolong baru dan unik menurut pandangan mereka, meski siswa merasa canggung dengan metode pembelajaran yang diberikan. Sehingga seolah-olah siklus I ini orientasinya siswa mengenali metode pembelajaran yang diimplementasikan dan guru mengenal karakter individu dan karakter kelas siswa. Hasil tes siswa setelah dilakukan pemberian tugas dan evaluasi mengalami peningkatan. Hal ini dapat dilihat dari meningkatnya skor rata-rata skor siswa selama penelitian ini dilakukan, hal ini berarti bahwa metode yang diimplementasikan mampu meningkatkan hasil belajar siswa, dan berkurangnya siswa yang memperoleh angka rendah. Skor rata-rata hasil belajar siswa jika dikonversikan kedalam kategorisasi skala lima berada dalam kategori tinggi yang pada mulanya berada pada kategori sedang. Hal ini menunjukkan bahwa hasil belajar sosiologi siswa meningkat.

Meskipun demikian masih perlu ditingkatkan karena belum mencapai skor maksimal. Hal ini disebabkan oleh siswa masih terbiasa dengan metode pembelajaran yang diterapkan di kelas selama ini yang pada umumnya bersifat teori saja dan siswa pada saat pembelajaran siswa hanya berperan sebagai penerima informasi dari guru, pengimplementasian metode pembelajaran team accelerated intruction juga dapat meningkatkan motivasi siswa 
untuk belajar sosiologi karena pembelajaran menuntut siswa untuk mencari, menemukan dan mengemukakan pendapatnya sendiri sesuai dengan kalimatnya sendiri tanpa keluar dari tujuan pembelajaran sehingga siswa bebas bertukar informasi tentang apa yang mereka dapatkan dari sub pokok bahasan masing-masing selain itu rasa percaya diri siswa dalam menyelesaikan permasalahan sosiologi meningkat.

Pengimplementasian metode pembelajaran team accelerated intruction menyebabkan siswa tidak bermalasmalasan lagi. Dengan cara ini pula siswa dapat lebih konsentrasi dalam memperhatikan pelajaran dan aktif dalam mengikuti proses belajar mengajar di kelas karena dapat memudahkan dirinya dalam menyelesaikan soal-soal yang diberikan, jika materinya sudah dipahami. Selain itu, dapat membuat siswa dan temantemannya mempunyai keinginan untuk belajar bersama dan bertukar pendapat jika mengalami kesulitan dalam belajar. Dari pembahasan di atas dapat dikatakan bahwa hasil penelitian ini mendukung teori yang sudah ada.

Dari hasil analisis kualitatif dan kuantitatif terlihat bahwa pada dasarnya pelaksanaan pembelajaran dengan menggunakan metode pembelajaran team accelerated intruction pada materi perubahan sosial (Contravention) dapat memberikan perubahan kepada siswa.

Peningkatan baik keaktifan, kehadiran maupun hasil belajar siswa pada siklus II, terjadi setelah diadakan perbaikan-perbaikan yang dianggap tidak terlaksana secara maksimal pada siklus sebelumnya yang diperoleh pada hasil observasi selama proses pembelajaran berlangsung. Adapun perbaikan yang sempat terlaksana adalah jika pada siklus I hanya siswa tingkat kecerdasan di atas rata-rata yang aktif dalam proses pembelajaran maka pada siklus II dilakukan pendekatan-pendekatan kepada siswa yang tingkat kecerdasan di bawah rata-rata untuk mendapatkan bimbingan secara langsung agar mereka lebih aktif dan dapat melibatkan diri dalam proses pembelajaran sesuai dengan metode pembelajaran yang diimplementasikan.

\section{KESIMPULAN}

Dari uraian di atas dapat disimpulkan pada siklus II pelaksanaan proses pembelajaran dengan menggunakan metode pembelajaran team accelerated intruction berjalan lebih baik lagi dibandingkan dengan siklus sebelumnya, Setelah diadakan refleksi pada siklus I, maka dilakukan kegiatan perbaikan demi 
peningkatan hasil belajar siswa pada siklus II, terlihat bahwa motivasi siswa sudah meningkat.

\section{DAFTAR RUJUKAN}

Arifin, Zainal. 2012. IImu Sosial Budaya Dasar. Makassar: Anugrah Mandiri.

Abdulsyani. 2012. Sosiologi Skematika,Teori,dan Terapan. Jakarta: Bumi Aksara.

Evaluasi Pendidikan, Jakarta. PT Raja Grafindo Persada

Hidrotum - Nisa,blokspot.gom.Minggu 1, april,2012

Huda Miftahul. 2013. Metode Pembelajaran Cooperative Learning. Jakarta: Pustaka Pelajar.

Hasan Iqbal M, 1999, Pokok-Pokok Materi Stastik 1, Bumi Aksara. Jakarta

Masnur Muslich. 2012. Penelitian Tindakan Kelas Sebagai Pedoman Praktis Bagi Guru Profesional. Jakarta: PT Bumi Aksara.

Nursito, 2002, Peningkatan Prestasi Sekolah Menengah, Insan Cendekia

Polma Margaret, 2007. Sosiologi Kontemporer, Jakarta. PT Raja Grafindo Persada.

Rusman. 2011. Model-model Pembelajaran Mengembangkan Profesionalisme Guru. Jakarta: Rajawali Pres.

Saptono. 206. Sosiologi SMA Kelas XII. Jakarta: Phibeta.

Soekanto, Soerjono. 2012. Sosiologi Suatu Pengantar. Jakarta: Rajawali Pers.

Soekanto Soerjono.2007, Sosiologi Suatu Pengantar, Jakarta. PT Raja Grafindo Persada

Sudijino Anas, 2006, Pengantar Evaluasi Pendidikan, Jakarta. PT Raja Grafindo Persada.
Sitorus. 1997. Sosiologi SMU. Bandar Lampung: Erlangga.

Sosiologi Kelas XII SMA dan MA, Dwi Mulyono, PT. Tiga Serangkai Pustaka Mandiri,2013, Solo.

Sosiologi Kelas XII SMA dan MA, Kun Maryati dkk, Exisw, Jakarta.

Trianto.2007.Model-model PembelajaranInovatifBerorientasiKon struktivistik. Jakarta: PrestasiPustaka Publisher. 2010. Penelitian Tindakan Kelas. Jakarta: Bumi Aksaran. 